\title{
Chinese Dynasties Since the Time of Unification Under the Han
}

Han dynasty

Period of the six dynasties

Sui dynasty

T'ang dynasty

206 B.C. - A.D. 220

220-589

589-618

Period of the five dynasties

618-907

Sung dynasty

907-960

Southern Sung dynasty (1127-1279)

$960-1279$

Yüan (Mongol) dynasty

$1279-1368$

Ming dynasty

$1368-1644$

Ch'ing (Manchu) dynasty

1644-1911 
